\title{
Effect of the rate of potassium chloride on dairy production in Taranaki
}

\author{
J. D. MORTON ${ }^{1}$, C.J. ROACH ${ }^{2}$ and A.H.C. ROBERTS ${ }^{3}$ \\ ${ }^{1}$ AgResearch, Invermay Agricultural Centre, PB 50034, Mosgiel \\ ${ }^{2}$ Dexcel, Whareroa Research Centre, R.D. 12, Hawera \\ ${ }^{3}$ Ravensdown Fertiliser, Box 608, Pukekohe \\ jeff.morton@agresearch.co.nz
}

\begin{abstract}
Potassium chloride $(\mathrm{KCl})$ was applied at 4 rates $(0,150$, 450 and $1150 \mathrm{~kg} / \mathrm{ha}$ ) to pasture on closed 5 ha farmlets over 3 years, and pasture and animal production and animal health measured. Friesan, Jersey and Friesan $x$ Jersey cows were stocked at 3.2/ha on an Egmont Allophanic soil near Hawera in South Taranaki. Average soil potassium quick test (QTK) levels were 7, 8, 10 and 12 respectively from $0,150,450$ and $1150 \mathrm{~kg} \mathrm{KCl} / \mathrm{ha}$. There was a small significant negative linear effect of rate of $\mathrm{KCl}$ application on annual pasture dry matter (DM) production averaged over three years (16864 $18359 \mathrm{~kg} / \mathrm{ha}$ ). The average amount of silage conserved $(1369-2112 \mathrm{~kg} \mathrm{DM} / \mathrm{ha})$ was consistently greater at the highest rate of $\mathrm{KCl}$. Increasing rate of $\mathrm{KCl}$ had no significant effect on the nutritive value of grazed pasture but resulted in increased $\mathrm{K}$ content of silage. There was no significant effect of $\mathrm{KCl}$ on milksolids (MS) production (1034-1179 kg/ha/lactation) or reproductive performance. There was a trend for the incidence of clinical metabolic disorders (8-18\%) to decrease with increasing rate of $\mathrm{KCl}$ but this was not significant because of the low number of cows in each herd. The results from this trial suggest that soil QTK levels above the target range for optimal pasture production of 7-10 on Allophanic soils are not associated with increased dairy production and have no adverse effect on animal health.
\end{abstract}

Keywords: calcium, dairy cows, hypocalcaemia, hypomagnesaemia, magnesium, milksolids, pasture, potassium, potassium chloride

\section{Introduction}

Some $40 \%$ of the dairying in the North Island of New Zealand is carried out on Allophanic (volcanic ash) soils in the Taranaki and Waikato regions (LIC 2003). Potassium required for pasture growth is supplied in only small amounts by Allophanic soils and needs to be applied in fertiliser. Plant-available $\mathrm{K}$ in the soil is measured in NZ by a quick test that uses ammonium acetate as the extractant. The soil QTK has been calibrated with pasture production from a number of mowing trials on ash soils that show near maximum yield occurring within the target range 6-8 (Roberts \& Morton 1999). Because $\mathrm{K}$ is recycled differently in mowing compared with grazing trials, it was considered worthwhile to verify this by measuring responses in pasture and MS production to soil QTK levels above the target range.

Reports from veterinarians in South Taranaki implicated the use of $\mathrm{KCl}$ together with di-ammonium phosphate (DAP) before calving in increases in the incidence of hypocalcaemia (e.g. Dairy Exporter, January 1996). The K status of soils, pastures and animals can affect the availability of calcium (Ca), magnesium $(\mathrm{Mg})$ and sodium $(\mathrm{Na})$. Morton et al. (2004) reported a greater amount of leached $\mathrm{Ca}$ and $\mathrm{Na}$ from increasing rate of $\mathrm{KCl}$ application at this site. The effect of $\mathrm{KCl}$ application on the pasture uptake of cations has ranged from large depressive effects (McNaught 1959 - Mg 53\%, Ca 43\%) to small effects, either at this site (Morton et al. 2004) and on sedimentary soils (Morton et al . 2000). Goff \& Horst (1997) reported that increasing $\mathrm{K}$ content in the pre-calving diet from 1.1 to 2.1 or $3.1 \%$ increased the incidence of milk fever from $10 \%$ to $50 \%$ or $48 \%$ and that all cows could be classified as sub-clinically hypocalcaemic at some time within the first day after calving. Sub-clinical hypocalcaemia can result in decreased cow appetite, feed intake and milk production, and also cow reproductive performance (Stevenson et al. 1999). High K diets have also been reported to interfere with the ruminal absorption of $\mathrm{Mg}$ (Martens \& Rayssiguier 1980), which can be a major source of hypomagnesaemia. Hypomagnesaemia can affect parathyroid hormone secretion that controls the mobilisation of $\mathrm{Ca}$ from bone and hence cause hypocalcaemia at calving (Fontenot et al. 1989). The association between rate of $\mathrm{KCl}$ application and the incidence of metabolic disorders was investigated in the three-year grazing trial reported in this paper.

\section{Materials and methods \\ Site}

The trial was sited on an Egmont ash (Allophanic) soil on the Whareroa Research Farm near Hawera in South Taranaki.

\section{Trial design and treatments}

A flat to undulating area was fenced into forty 0.5 ha paddocks and soil QTK to $7.5 \mathrm{~cm}$ measured in each paddock. The treatments were then allocated to each of ten paddocks/farmlet so that the initial mean QTK level was similar (Table 1). The treatments were: 


\section{K0 $0 \mathrm{KCl}$}

$\mathrm{K} 1150 \mathrm{~kg} \mathrm{KCl} / \mathrm{ha}$ a pplied in April 2000

$\mathrm{K} 3450 \mathrm{~kg} \mathrm{KCl} / \mathrm{ha}$ applied in April 2000 (300 kg/ha) and April 2001 (150 kg /ha)

K4 $1150 \mathrm{~kg} \mathrm{KCl} / \mathrm{ha}$ applied in April 2000 (450 kg/ha), April 2001 (300 kg/ha), August 2002 (200 kg/ha) and October $2002(200 \mathrm{~kg} / \mathrm{ha})$

High rates of $\mathrm{KCl}$ were applied to $\mathrm{K} 2$ and $\mathrm{K} 3$ to achieve a wide range of soil QTK levels.

\section{Management}

The 10 paddocks in each farmlet were rotationally grazed by 3.2 Friesan, Jersey and Friesian $\mathrm{x}$ Jersey cows/ ha (16 per farmlet) with a 30-day grazing interval from August to April and a 100-day grazing interval for the remainder of the year. The pasture sward consisted on average of approximately $65 \%$ perennial ryegrass (Lolium perenne), 30\% other grasses including cocksfoot (Dactylis glomerata), Yorkshire fog (Holcus lanatus) and some Poa species, $2.5 \%$ white clover (Trifolium repens) and $2.5 \%$ weeds on a DM basis. Pre-grazing pasture mass averaged $3900 \mathrm{~kg} \mathrm{DM} / \mathrm{ha}$ and post-grazing pasture mass averaged $1850 \mathrm{~kg} \mathrm{DM} / \mathrm{ha}$ across all farmlets. When post-grazing pasture mass exceeded that level, the paddock was removed from grazing and harvested for silage. Pasture silage conserved on each farmlet at $3 \mathrm{~kg} \mathrm{DM} / \mathrm{cow}$ was fed to the cows during winter and calving (until mid-August in 2000 and 2001 and late-August in 2002).

Causmag (magnesium oxide) was dusted daily on to pastures at $85 \mathrm{~g} / \mathrm{cow} /$ day from early-July (pre-calving) to the end of October in 2000 and 2002. In 2001, as part of another trial, each cow was drenched with magnesium oxide (MgO), chloride or sulphate at $20 \mathrm{~g} \mathrm{Mg} / \mathrm{cow} /$ day (balanced between $\mathrm{K}$ treatments) from early-July until calving (mid-July) with pasture dusted with $\mathrm{MgO}$ from calving until the end of October as in the other two years. Superphosphate to supply $59 \mathrm{~kg}$ phosphorus $/ \mathrm{ha}$ and $72 \mathrm{~kg}$ sulphur/ha was a pplied in November of each year. Urea to supply $80 \mathrm{~kg}$ nitrogen $(\mathrm{N}) / \mathrm{ha}$ in 2001/2002 and 197 $\mathrm{kg} \mathrm{N} / \mathrm{ha}$ in 2000/2001 and 2002/2003 was applied in single applications of $22-60 \mathrm{~kg} \mathrm{~N} / \mathrm{ha}$ from July to April.

\section{Measurements}

\section{Soil}

In May of each year, 15 soil cores to $7.5 \mathrm{~cm}$ depth were sampled (excluding visible excreta patches as per the sampling protocol for commercial dairy farms) from each paddock and analysed for QTK, $\mathrm{Mg}, \mathrm{Ca}$ and $\mathrm{Na}$ using an ammonium acetate extraction.

\section{Pasture}

Pasture DM production was determined in each paddock by weekly visual assessment of pasture mass in grazed and silage paddocks during the lactation and two-weekly assessment during non-lactation. This assessment was corrected using calibration cuts from ten $0.1 \mathrm{~m}^{2}$ quadrats of pasture in grazed and silage paddocks trimmed to ground level, and a sub-sample dried for 12 hours at $90^{\circ} \mathrm{C}$.

The nutritive value of pasture was assessed by NIRS from monthly measurements of metabolisable energy (ME), organic matter digestibility (OMD), crude protein (CP) and acid detergent fibre (ADF) from October to December. The cation content of pasture in each paddock was also measured before being cut for silage.

\section{Animal}

During and after calving in each year, the number of cows in each group that showed the behavioural symptoms of clinical hypocalcaemia and hypomagnesaemia and received treatment using a precautionary approach, were recorded. Reproductive performance was also monitored through the recording of critical measures such as submission rate, pregnancy rate and total number of matings/cow. Milksolids production for each cow was measured twice-weekly during each lactation.

\section{Statistical analysis}

Data was analysed for linear treatment effects by ANOVA using GENSTAT.

\section{Results}

\section{Soil}

There was a significant effect of rate of $\mathrm{KCl}$ on soil QTK levels $(\mathrm{P}<0.01)$ in all years (Table 1). The lower QTK levels in 2002 were consistent with soil test results from the remainder of the farm and could not be readily explained.

\section{Pasture}

Pasture production

Averaged over all three years, there was a significant negative linear effect $(\mathrm{P}<0.05)$ of rate of $\mathrm{KCl}$ on total pasture production (Table 2). For silage production there was a significant linear increase with increasing rate of $\mathrm{KCl}$ but the most consistent effect was the greater silage production from the highest rate of $\mathrm{KCl}$.

Nutritive value of grazed pasture

There was no significant effect $(\mathrm{P}<0.05)$ of rate of $\mathrm{KCl}$ on ME (10.3-10.6 MJ/kg DM), OMD (73.9-76.6\%), CP (19.8-25.0\%) and ADF (26.9-29.0\%).

\section{Silage mineral content}

There was a significant effect $(\mathrm{P}<0.05)$ of $\mathrm{KCl}$ on the $\mathrm{K}$ content (2.72-4.04\%) of silage but no significant effect 
Table 1 Effect of rate of $\mathrm{KCl}$ on soil QTK levels.

\begin{tabular}{ccccccc}
\hline Year & K0 & K1 & K2 & K3 & SED & $\begin{array}{c}P \text { value } \\
\text { Linear K trend }\end{array}$ \\
\hline 2000 & 7.4 & 6.6 & 6.8 & 7.3 & & \\
2001 & 7.3 & 9.2 & 13.6 & 18.5 & 1.67 & $<0.001$ \\
2002 & 5.5 & 7.8 & 8.1 & 8.5 & 1.46 & 0.001 \\
2003 & 7.3 & 8.6 & 10.5 & 15.4 & 2.00 & 0.0019 \\
\hline
\end{tabular}

Table 2 Effect of rate of $\mathrm{KCl}$ on total pasture (including silage) and silage DM production $(\mathrm{kg} / \mathrm{ha})$.

\begin{tabular}{lcccccc}
\hline Year & K0 & K1 & K2 & K3 & SED & $\begin{array}{c}\text { P value } \\
\text { Linear K trend }\end{array}$ \\
\hline 2000/2001 & & & & & \\
Pasture & 17118 & 15803 & 14671 & 16017 & 2803 & 0.317 \\
Silage & 1280 & 1763 & 1638 & 2141 & & 0.382 \\
2001/2002 & & & & & \\
Pasture & 21113 & 20803 & 19388 & 19904 & 2555 & 0.214 \\
Silage & 1309 & 1718 & 1354 & 1910 & & 0.360 \\
2002/2003 & 18359 & 16026 & 16533 & 15991 & 2161 & 0.340 \\
Pasture & 1123 & 1472 & 1472 & 2077 & & 0.068 \\
Silage & & & & & & \\
Average of 3 years & 18863 & 17544 & 16864 & 17304 & 718.2 & 0.024 \\
$\begin{array}{l}\text { Pasture } \\
\text { Silage }\end{array}$ & 1369 & 1734 & 1503 & 2112 & 120.4 & 0.002 \\
\hline
\end{tabular}

Table 3 Effect of rate of $\mathrm{KCl}$ on the percentage of cows treated for clinical metabolic disorders (average of 3 years).

\begin{tabular}{lcccccc}
\hline Year & K0 & K1 & K2 & K3 & SED & $\begin{array}{c}\text { P value } \\
\text { Treatment effect }\end{array}$ \\
\hline Hypocalcaemia & 12 & 14 & 8 & 8 & 6.5 & 0.756 \\
Hypomagnesaemia & 6 & 2 & 2 & 0 & 3.1 & 0.316 \\
Total & 18 & 16 & 10 & 8 & 5.6 & 0.317 \\
\hline
\end{tabular}

Table 4 Effect of rate of $\mathrm{KCl}$ on MS production $(\mathrm{kg} / \mathrm{ha})$ in each lactation.

\begin{tabular}{llccccc}
\hline Lactation & K0 & K1 & K2 & K3 & SED & $\begin{array}{c}\text { P value } \\
\text { Linear K trend }\end{array}$ \\
\hline $2000 / 2001$ & 1158 & 1110 & 1034 & 1120 & 68.3 & 0.538 \\
$2001 / 2002$ & 1157 & 1119 & 1096 & 1122 & 74.7 & 0.345 \\
$2002 / 2003$ & 1120 & 1179 & 1107 & 1154 & 56.1 & 0.887 \\
\hline
\end{tabular}


on other plant cations (results not shown).

\section{Animal}

\section{Incidence of metabolic disorders}

The incidence of clinical hypocalcaemia and hypomagnesaemia in each farmlet herd decreased with increasing rate of $\mathrm{KCl}$ (Table 3). However, the small number of cows in each farmlet herd reduced the possibility of significant effects.

\section{Milksolids production}

There was no significant effect of $\mathrm{KCl}(\mathrm{P}<0.05)$ measured on MS production/ha (Table 4).

\section{Cow reproduction}

Six week submission and final pregnancy rate (88$100 \%)$ and total number of matings/cow (1.30-1.89) were not significantly affected by rate of $\mathrm{KCl}(\mathrm{P}<0.05)$. It is recognised that it is difficult to detect significant effects on reproductive performance unless cow numbers/ group are much greater than were present in this trial.

\section{Discussion}

There have been no previous trials where results have been reported on pasture and milk production responses to $\mathrm{K}$ fertiliser under dairying in NZ. Although this trial was set up primarily to measure the effect of soil and pasture $\mathrm{K}$ status on the incidence of metabolic disorders and the effect of rate of $\mathrm{K}$ fertiliser on the major cations in soil, pasture and leachate (Morton et al. 2004), it also provided some useful information on production responses to $\mathrm{K}$.

The target soil QTK test for near-maximum pasture production on Allophanic (ash) soils were determined from several small plot mowing trials to be in the range 7-10 (Roberts \& Morton 1999). Since there was no increase in pasture and MS production in the farmlets where increasing rates of $\mathrm{KCl}$ increased soil QTK levels above the target range, this range of 7-10 was verified from these results. The maintenance of soil QTK levels for three years where no fertiliser $\mathrm{K}$ was applied suggested either that $\mathrm{K}$ cycling through urine from high stocking densities in small paddocks was very efficient or that $\mathrm{K}$ was supplied to the pasture from nonexchangeable pools in the soil.

The increase in silage DM production at the highest rate of $\mathrm{KCl}$ and soil QTK level was not expected since the $\mathrm{K}$ content of the pasture in the silage paddocks was within or above the optimum range for vegetative growth (2.5-3.0\% - Roberts \& Morton 1999). Visually assessed clover content was low (7\%) in all pastures (results not shown) so the greater response to $\mathrm{K}$ could not be attributed to more K-responsive clover in the silage pad docks. An effect of high pasture K content (>3.4\%) reducing cow grazing preference for pasture in South Taranaki was measured in the late spring of 2000 and 2001 but no effect of $\mathrm{K}$ content on pasture intake was measured in 2002 (Morton et al. 2005). In 2001 and 2002 , the measurements were carried out on this site. Therefore any possible indirect effect of cows rejecting pasture resulting in more being surplus and shut up for silage can probably be discounted.

In this trial, increasing rate of $\mathrm{KCl}$ only had a small depressive effect on pasture $\mathrm{Ca}$ and $\mathrm{Mg}$ contents (Morton et al. 2004), so there should have been no effect of $K$ on $\mathrm{Ca}$ and $\mathrm{Mg}$ intake by cows from pasture. At calving in July, pasture Ca contents in each famlet averaged $0.40 \%$ and pasture $\mathrm{Mg}$ contents averaged $0.23 \%$ (Morton et al. 2004). These levels were below the pasture Ca content of $0.60 \%$ and pasture $\mathrm{Mg}$ content of $0.28-0.35 \%$ required to avoid metabolic disorders in cows grazed outdoors and producing $1.75 \mathrm{~kg} \mathrm{MS} /$ day or more (Roche pers. comm.). This would have contributed to the recorded incidences of clinical hypocalcaemia and hypomagnesaemia.

Pasture $\mathrm{Ca}$ content alone is not an accurate indicator of adequacy of $\mathrm{Ca}$ supply to the cow because $\mathrm{Ca}$ demand from the blood at calving and the start of lactation is so high that it relies on the withdrawal of $\mathrm{Ca}$ from bone or by increasing the efficient absorption of dietary $\mathrm{Ca}$ (Fontenot et al. 1989 ). Blood plasma Ca concentrations at calving in 2000 and the day following calving were unaffected by pasture $\mathrm{K}$ contents but significantly increased linearly 2 days post-calving with increasing dietary $\mathrm{K}$ intake (Roche et al. 2002). At this stage, approximately $3 \%$ of cows had plasma Ca concentrations $<1.4 \mathrm{mmol} / \mathrm{l}$ indicating clinical hypocalcaemia (Roche et al. 2002) which was lower than the $8 \%$ of cows that were treated for hypocalcaemia in 2000 . The incidence of sub-clinical hypocalcaemia (plasma $\mathrm{Ca}<2 \mathrm{mmol} / \mathrm{l}$ Thilsing-Hansen \& Jorgenson 2001) was $40 \%$ with no measured effect of $\mathrm{KCl}$ (Roche et al. 2002).

Although pasture $\mathrm{K}$ contents were higher in our trial (3.5-4.5\%) than the highest $\mathrm{K}$ content of the feed (3.1\%) offered by Goff \& Horst (1997), the incidence of hypocalcaemia, as indicated by plasma $\mathrm{Ca}$ concentrations, was much lower (Roche et al. 2002). This difference in the effect of $\mathrm{K}$ on the incidence of hypocalcaemia was attributed by Roche et al. (2002) to be partly due to the use of more susceptible older Jersey cows by Goff \& Horst (1997). Plasma concentrations of Mg on the day of calving or the two days post-calving in the reported trial $(0.58-0.73 \mathrm{mmol} / \mathrm{l})$ were not affected by dietary $\mathrm{K}$ content (Roche et al. 2002).

\section{Conclusions}

At this trial site, the hypothesis that high application rates of $\mathrm{KCl}$ are associated with an increase in the 
incidence of metabolic disorders in dairy cows, was not proven. The target range of soil QTK levels for nearmaximum pasture production on Allophanic soils was confirmed as being in the range 7-10.

\section{ACKNOWLEDGEMENTS}

We thank Claire Cooper for helping initiate the trial, Marie Tong and Sarah Gooch for helping with the measurements, the Whareroa Research Farm staff for managing the animals, Barbara Dow for statistical analysis and John Roche for helpful advice.

\section{REFERENCES}

Fontenot, J. P.; Allen, V.G.; Bunce, G.E.; Goff, J.P. 1989. Factors influencing magnesium absorption and metabolism in ruminants. Journal of Animal Science 67: 3445-3455.

Goff, J.P.; Horst, R.L. 1997. Effects of the addition of potassium or sodium, but not calcium, to prepartum rations on milk fever in dairy cows. Journal of Dairy Science 80: 176-186.

LIC 2003. New Zealand Dairy Statistics 2001-2002. Livestock Improvement Corporation, Hamilton,

Martens, H.; Rayssiguier, Y. 1980. Magnesium metabolism and hypomagnesaemia. pp. 477. In: Digestive physiology and metabolism in rumens. Ed. Ruckebusch, Y.T. MTP Press Ltd, Lancaster, UK.

McNaught, K.J. 1959. Effect of potassium fertiliser on sodium, magnesium and calcium in plant tissues. New Zealand Agriculture 99: 42.

Morton, J. D.; Smith, L. C.; Roberts, A.H.C.; O'Connor,
M.B.; Hunt, B.L. 2000. The effect of fertiliser potassium and nitrogen on minerals required by dairy cows. In Soil Research: A knowledge industry for land-based exporters. (Eds L D Currie and P Loganathan). Occasional report No. 13. Fertiliser and Lime Research Centre, Massey University, Palmerston North. pp 197-210.

Morton, J.D.; Roach, C.G.; Tong M.J.; Roberts, A.H.C. 2004. Potassium in soil and pasture and leaching of cations on an allophanic soil in New Zealand. New Zealand Journal of Agricultural Research 47: 147-154.

Morton,J.D.; Roach,C.G.; Roberts, A.H.C. 2005. Effect of potassium content and dusting of sodium chloride on the pasture preference of dairy cows. New Zealand Journal of Agricultural Research 48: 29-37.

Roberts A.H.C.; Morton J.D. 1999. Fertiliser use on dairy farms. Dexcel/FertResearch/ AgResearch publication. $38 \mathrm{pp}$.

Roche, J.R.; Morton, J.; Kolver, E.S. 2002. Sulfur and chlorine play a non-acid base role in periparturient calcium homeostasis. Journal of Dairy Science 85: 3444-3453.

Stevenson, M.A.; Williamson, N.B.; Hanlon, D.W. 1999. The effects of calcium supplementation of dairy cattle after calving on milk, milk fat and protein production, and fertility. New Zealand Veterinary Journal 97: 5360.

Thilsing-Hansen, T.; Jorgenson, R.J . 2001. Prevention of parturient paresis and subclinical hypocalcaemia in dairy cows by zeolite A administration in the dry period. Journal of Dairy Science 84: 691-693. 